\title{
Pragmatic Presupposition in Waspada Daily Articles
}

\author{
Umar Monoํ, Dian Marisha Putri ${ }^{1}$, Liza Amalia Putri ${ }^{1}$ \\ ${ }^{1}$ University of Sumatera Utara (USU), Indonesia \\ Email: amri lubis@ymail.com
}

\begin{abstract}
An article of editorial is the key of newspaper which is the editor's point of view toward an actual event that is popular when it is published. The editor provides information such as events, incidents, facts or opinion so that readers know and understand it. The objectives of the research results are: Firstly, to describe kinds of presuppositions found in Waspada daily news. Secondly, out of all data, 6 articles or editorials, there are 201 sentences with presuppositions consisting of individual, existential, lexical, factive, structural, non-factive, and counter factive presupposotions. The data show that readers must have knowledge and situational context in order to make presupposition. The articles on Waspada daily news can be made teaching materials of Presupposition in Pragmatics. Among all speech acts, there is also a presupposition made by a speaker to the listener.
\end{abstract}

Keywords: presupposition; pragmatics; article

\section{Introduction}

An article of editorial is the key of newspaper which is the editor's point of view toward an actual event that is popular when it is published. It is essential actual event, problem, editor's opinion, criticism, suggestion and hope to readers. Before an article is written, the editor assumes that the readers have knowledge about the topic un form of pragmatic presupposition. The editor writes the article effectively based on of the presupposition understood by the readers explicitly or implicitly. However, explicit presupposition is not easily understood by the readers, especially implicit presupposition that can become problems because the editor does not realize that he uses sentences that are difficult to be understood by the readers. Based on this problem, a pragmatic study can help readers understand the article text through its context which is delivered by considering who, where, when, and under what circumstance it is. Yule (1996) calls it 'the study of contextual meaning' (study on meaninig based on context). When the readers understand this context, they will understand the information intended to be delivered by the article. Based on this problem, this researchers try to study, How are the forms of presuppositions found in Waspada daily news article?

\section{Theoretical Framework}

Pragmatics as one of linguistic studies, specially studies the correlation between language and speech context. Parker's opinion in Rahardi (2005:49) states that "pragmatics is 
distinct from grammar, which is the study of the internal structure of language. Yule (1996) states that there is regularity in communication. This regularity becomes the guide for utterers/writers. A part of pragmatic study is presupposition.

Frege in Finch (2000) states that 'presupposition refers to implicit information of proposition embedded in a sentence or utterance'. Presupposition is used as the communication strategy to avoid; language users (speaakers/writers) do not describe all relevant details of the topic discussed. Presupposition is what is used by a writer as the mutual ground for conversation members (Stalnaker in Rustono 1999:105). Mutual groud is a presupposition that can be understood by both writer and readers in writtem communication.

The concept of presupposition is firstly introduced by a Germany logician in 1892 named Frege. Frege in Finch (2000). According to Yule (1996:27) trigger as 'indicators of potential presupposition' which can be trusted by the speakers toward the context'. Saeed (1917:97) states that trigger as 'other types of presupposition produced by particular words or construction'. Levinson (1983:179) calls presupposition as 'generating linguistic items' of presupposition.

The use of presupposition can cause different interpretations between writer and readers. Yule (1996:27) classifies types of presuppositions into: a) the existensial presupposition, $b$ ) the factive presupposition, $c$ ) the nonfactive presupposition, $d$ ) the lexical presupposition, $e$ ) the structural presupposition, and $f$ ) praanggapan the counter factive presupposition.

\section{Research Methodology}

This is a qualitative research with descriptive method, to analyze the data from Waspada daily news articles. The research employs descriptive qualitative method so that the data obtained are sourced from Waspada daily, especialy, article text in Editorials. Interactive analysis is used as data analysis technique, consisting of data reduction, collecting, presentation and conclusion. The research procedures consist of some steps. The first step is organizing research proposal, data collecting method, and analysis. The second step is collecting, reducing, presenting and verifying data. The third step is organizing research result. Descriptive qualitative approach is emplyed in this research; which primary data are obtained from Waspada daily news articles. This research is done in Study Program of English Literature, Faculty of Cultural Science in Universitas Sumatera Utara. From April, 2018 until Desember, 2018. The source of the primary data is Waspada Daily news article which are analyzed by presupposition and the secondary data are sourced from journals and reference.

\section{Research Results}

According to the data analyzed, namely 6 articles of editorials in Waspada daily news, they are:1) article on Monday, March 19, 2018 entitled "Bersama Kita Lawan Hoax' (Together We Fight Hoax), 2) article on Monday, April 2, 2018 entitled "PR Berat Pasca Kongres" (Great Homework after Congress), 3) article on Saturday March 31, 2018 entitled "Congress of Moslems in North Umatera Province for the Sake of the Nation", 4) article on 
Tuesday, arch 27, 2018 entitled "Prabowo Butuh Semangat 212" (Prabowo needs the spirit of 212), 5) article on Monday, March 26, 2018 entitled "PDIP-Demokrat Panas" (PDIPDemokrat are heated up), and 6) article on March 24, 2018 entitled "Kontroversi PrabowoAmien" (Controversy of Prabowo-Amien). Based on the analaysis of the data, it find out the forms or types of presuppositions, namely:

\section{i. The Existensial Presupposition}

In the editorial entitled "Together We Fight Hoax", the writer writes:

a) Pilkada (Election of Regional Government Leaders) is the celebration of democracy. The people are supposed to party, to have fun. Thus, do not let pilkada be used to get people disrupted by irresponsible persons (A1/K2/PE),

b) The more massive the campaign is, the better it is (A1/K8/PE),

When the meaning of the sentence is analyzed a) the meaning is: "Do not let irresponsible person make Pilkada as a tool to disrupt people." The presupposition in the text is that there is a person who intends to disrupt people in the election campaign. The text cannot be determined whether it is right or wrong, because there is not anyone who is put into trial because of having disrupted the people.

The article text means, "The more massive the campaign is, the better it is." $(\mathrm{A} 1 / \mathrm{K} 8 / \mathrm{PE})$. The text does not only intend to inform the readers that "The more massive the campaign is, the better it is," but also to explain that the campaigns are massive as they take part in social and charity activities. It is meant to say that there are people who have done things as intended by the txt in the article, that there is implicit meaning in the text, it is: "the canpaign that is done masively will certainly make it better." This Existential presupposition is related to the existence of ownership.

It is not only assumed to be present in the construction of the sentences that show ownership, but more than that, it shows the existence of statements in the article text with its use in the first sentence 'Layaknya' (supposed to) and 'kampanyenya' (the campaign) means that there is the pronoun describing to one's possession. So, existential presupposition shows how the existence of something can be delivered through presupposition; for example, Do not let pilkada be used to get people disrupted by irresponsible persons. The presupposition in the text makes statement of existence, namely: 1) That there is a person who registered in Pilkada, 2) There is a person who campaign in Pilkada, 3) There are persons who get people disrupted in pilkada. There are many presuppositions can be drawn from the text.

\section{ii. The Factive Presupposition}

According to the factive data in Waspada daily news article, there are 12 factive presuppositions meaning that the subject realizes the impact of hoax, so that they make a vow and refuse ethnical, religious, and racial issues by putting signature through expression of hatred such as: a) Kapolrestabes Medan (Head of Police Station of Medan City) with the chief of journalist organization vow to refuse ethnical, religious, and racial issues, hoax and expression of hatred to make peace and security approaching Pilkada that is simultaneously held on June 27, 2018. (Al/K1/PF), b) They put their signatures on the vow board bearing in mind that North Sumatera Province is the barometer of Indonesia; thus, everyone is committed to create harmoniousPilkada and elect a quality leader. mengingat Sumut merupakan barometer Indonesia karena itu semua yang hadir berkomitmen untuk menciptakan Pilkada yang hannonis dan menghasilkan pemimpin berkualitas. (A1/K4/PF). 
The factive verbs in data a) vow and b) sign the vow board, trigger presupposition that kapolrestabes with the head of journalist organization vow to refuse ethnical, religious, and racial issues, hoax and expression of hatred. The factive verbs in data b) sign the vow board, triggers common knowledge about what is being talked, experienced from what is observed praanggapan faktif sebagai pengetahuan bersama mengenai yang sedang dibicarakan, dialami or seen as a fact sebagai fakta, that there is ethnical, religious, and racial issuesalready, hoax and expression of hatred delivered in the campaing during pilkada. The data from the above text show that there is already a fact from what is observed or seen, namely 'ethnical, religious, and racial issues, hoax and expression of hatred.' .

\section{iii. The Nonfactive Presupposition}

There are 8 nonfactive presuppositions found in Waspada daily news text. One of the examples of text analysis containing presupposition that is not true are represented in the words such as 'lie story, misleading news, fake news, vilification, ethnical, religious, and racial issues, hoax'. For example:

a) There are so many lie stories, spreading hatred to particular parties kebwhich are even leading to ethnical, religious, and racial issues. (A1/K10/PNF)

b) ...in the social media user circle, there are thousands of fake news. (A1/K18/PNF)

c) Finally, positive media is defeated by fake media.. (A1/K25/PNF)

The italic and bold words contain non-factive presuppositions. They are: "There are so many lie stories, spreading hatred to particular parties kebwhich are even leading to ethnical, religious, and racial issues." $(A 1 / K 10 / P N F)$ " The text makes presupposition of lie story... so many, about the condition which is not like the reality.

This text is described as follows, '..in the social media user circle, there are thousands of fake news'. Non-factive presuppositions can be assumed through the text which truth is still doubted with the fact it states or it shows condition contrary to the reality. Finally, if there are thousands of fake news, and that needs verification. Presupposition requires common knowledge between the writer and readers. The common knowledge here is Pengetahuan bersama di sini adalah '..in the social media user circle, there are thousands of fake news'. The conversation shows that the common knowledge required is the topic that is being discussed. So, it is true that this sentence contains non-factive presupposition.

\section{iv. The Lexical Presupposition}

There are 8 lexical presuppositions found using one lexical which presupposition is interpreted conventionally with other presuppositions that has already been contained therein. The word 'requested, positive news, professional media, do not spread,' contains sentence presupposition; when it is negated, the presupposition will describe that there will we disruption and unkindness among the society, in the sentence.

a) The society is demanded to read news in positive media, especially the verified daily newspaper (Al/K20/PL)

b) If people read positive news, they will receive true and useful information. (A1/K22/PL)

c) That is why it takes awareness to fight hoax news by buying and reading professional media. $(A 1 / K 26 / P L)$

d) The higher the society's awareness is, the better it will be. (A1/K27/PL)

e) Whenever you find information that is a hoax which tends to create conflict, which contain is misleading and attacks certain group of people, do not spread it.(A1/K33/PL) 
The articles in Waspada daily news create presuppositions of: a) The society is demanded to read news in positive media, especially the verified daily newspaper. Data b) If people read positive news, they will receive true and useful information creates presuppositions that there are many people read hoax, lie, and fake news. Data c) That is why it takes awareness to fight hoax news by buying and reading professional media. (A1/K26/PL) When understood conventionally, presupposition will be found, and d) The higher the society's awareness is, the better it will be. The presupposition will be understood when it is perceived conventionally Whenever you find information that is a hoax which tends to create conflict, which contain is misleading and attacks certain group of people, do not spread it.

The situational context is the common knowledge that is known by the text readers. This common knowledge is needed to understand the issue, who is being discussed. So, this sentence truly contains lexical presupposition. Lexical presupposition is the presupposition which meaning is interpreted conventionally with other understood presupposition (which is not stated).

\section{v. The Structural Presupposition}

There are 7 structural presuppositions related to the structure of sentence which conventionally contains regularity that is well assumed that is correlated with the use of certain words and phrase. The writer gives information that must be received as true news by readers. So, the characteristic is the use of question words such as: 'who', 'what', 'where', 'why', and 'how'. For example: What is democracy celebration? The text describes presupposition: election of heads of regional government. How about the mindset of the people? Who is punished?

a) Pilkada is the celebration of democracy. (A1/K2/PS)

b) People's mindset is expected to change and to be careful in responding negative information in social media (A1/K10/PS)

c) Hoax news will be imposed sanction by Board of Press. (A1/K25/PS)

There is common knowledge from the above text. So, these sentences contain structural presupposition, in which the sentence structure is already precise without looking back at the previous sentence.

\section{vi. The Counter Factive Presupposition}

There are 8 sentences in Waspada daily news articles containing counter factive presuppositions. These presuppositions are not only wrong, but they are also contrary to the truth. When people no longer care, negative news can be perceived true by society. $(A 1 / K 12 / P F)$

a) Hoax news will be imposed sanction by Board of Press. (A1/K24/PE)

b) It is unfortunate if congress is held merrily, successfully, and .. (A2/K5/PE)

c) If it is possible, moslems in the world also refer to it to settle any kind of problems... $(A 2 / K 7 / P E)$

d) If KPK (Corruption Eradication Committee) can prove it with assistance from... (A5/K37/PE)

e) If Indonesia is said to be dispersed in 12 years... (A6/K14/PE)

The italic bold words contain counter factive presuppositions, they are a) When people do not care, $b$ ) If the news is hoax. c) It is unfortunate, d)If it is possible, e) Kalau KPK bisa membuktikannya, $f$ ) If Indonesia is said to be dispersed, it should, these presuppositions are 
created from conditional sentences. The use of the words 'if' makes contradictive presupposition of the utterance. The context of the text occurs when the writer and readers have common knowledge.

\section{Conclusion}

There are six types of presuppositions found in Waspada daily news article consisting of 201 sentences; they are existential presupposition, factive presupposition, lexical presupposition, structural presupposition, non-factive presupposition, and counter factive presupposition. Presuppositions in article contain a presupposition made by the writer as the communication strategy to avoid; hoping that the readers can understand the meaning delivered. The editorials of Waspada daily news function as the study source to understand the writer's point of view and how the readers understand the topic that is being discussed in the articles, so that the readers need to understand the context to reduce understanding bias between the writer and readers about the topic.

\section{References}

Caffi, C 1993. Pragmatik Presupposition in Enclicopedia of language and Linguistics. Oxford: Pergamon.

Finch, G. 2000. Key Concept in Language and Linguistics. Hamshire: Palgrave Macmilan Levinson, S. 1983. Pragmatics. Cambridge : Cambridge University Press.

Miles, Metthew B and A. Michael Huberman. 2014. Qualitative Data Analysis A Methods Sourcebook. Third edition. Sage: Los Angelos United States of America.

Rahardi, K. 2005. Pragmatik: Kesantunan Imperatif Bahasa Indonesia. Jakarta: Penerbit Erlangga.

Rustono. 1999. Pokok-pokok Pragmatik. Semarang: CV IKIP Semarang Press.

Leech, Geoffrey. 1993. Prinsip-Prinsip Pragmatik. Terjemahan M.D.D. Oka. Jakarta: UI.

Leech, Geoffrey. 1982. The Principles of Pragmatics. Terjemahan. Oka, M.D.D. dan Setyadi Setyapranata (Penerjemah). 1993. Prinsip-Prinsip Pragmatik. Jakarta: Universitas Indonesia Press.

Milas, Matthew B dan Huberman, A. Michael .1992. Qualitative Data Analysis. Alih Bahasa Tjetjep Rohendi Rohidi. Jakarta. Penerbit Universitas Indonesia.

Moleong, Lexi. 2007. Metodologi Penelitian Kualitatif (Edisi Revisi). Bandung: Remaja Rosdakarya.

Yule, George. 2006. Pragmatik. Terjamahan Indah Fajar Wahyuni. Yogyakarta: Pustaka Pelajar.

Yule, G. 1996. Pragmatics. Oxford: Oxford University 